\title{
Yhtä suurta keskiluokkaa?
}

Tarja Tolonen (toim.) (2008). Yhteiskuntaluokka ja sukupuoli. Nuorisotutkimusverkosto/Nuorisotutkimusseura julkaisuja 83. Vastapaino.

$\mathrm{M}$ uutama vuosikymmen sitten yksi jos toinenkin taisi saada yliannostuksen yhteiskuntaluokista ja luokkatietoisuudesta. Moni keskustelija kevensi sanastoaan ja ryhtyi puhumaan esimerkiksi elämäntavoista tai yksilöllisistä tyyleistä. Suomessahan kaikki ovat yhtä suurta keskiluokkaa, eikö totta?

Luokka näyttää kuitenkin palaavan tutkimuksen ja yhteiskunnallisen keskustelun asialistalle pohjoismaisissa hyvinvointivaltioissakin. Ruotsissa klassresa, luokkaretki, eli siirtymä koulutuksen kautta alemmista luokista ylempiin, on tullut osaksi aivan arkisiakin keskusteluja. Myös Suomessa on havahduttu luokkakeskusteluun. Tarja Tolosen toimittama Yhteiskuntaluokka ja sukupuoli on tässä rintamassa ihan etujoukoissa.

Uusin tutkimus pyrkii näkemään yhteiskuntaluokat muinakin kuin materiaalisina suhteina. Toki niiden perusta on taloudessa, mutta kyse on myös lukuisista erilaisista kulttuurista käytännöistä. Luokkarakenteet näkyvät arjessa sosioekonomisina, kulttuurisina ja valtaan liittyvinä eroina, joihin törmätään niin koulutuksessa, työpaikoilla kuin nuorisokulttuureissakin. Luokan käsite auttaa kohdentamaan katsettaan nimenomaan yhteiskunnallisiin rakenteisiin; kyse ei ole sattumanvaraisesta resurssien epätasaisesta jakautumisesta.

Yhteiskuntaluokka ja sukupuoli -kirja jakautuu viiteen osaan, josta kahdessa jälkimmäi- sessä keskitytään koulutuksen maailman ja sen jälkeiseen työelämään.

Näkökulmat ovat moninaiset. Saara Tuomaala analysoi 1900luvun alun jatko-opetusta koskevia keskusteluja. Kansakoulua ja korkeintaan parin vuoden jatkokursseja pidettiin maalaisnuorisolle riittävinä, sillä oppikoulu oli varattu sivistyneistön lapsille. Esimerkiksi Snellman paheksui kansaa, joka halusi työntää poikiaan opintielle, päätymään "puolivillaisiksi herroiksi”. Kahden sivistyksen perinne jatkui Suomessa 1960-luvulle asti, jolloin peruskoulu toteutti toiveet kaikille yhteisestä pohjakouluseurauksena oli tietynlainen paradoksi: yleissivistävä, teoreettinen tiedonihanne syrjäytti peruskoulun myötä ruumiillisuuteen ja konkreettisuuteen perustuvan työkasvatuksen ja oli näin omiaan marginalisoimaan osan työläisnuorista.

Katri Komulaisen, Maija Korhosen ja Hannu Rädyn kirjoituksessa kohdennetaan huomio nykyiseen globaaliin markkinatalouteen kytkeytyvään koulutusajatteluun. Artikkelissa tarkastellaan nuorten ainekirjoitusten pohjalta heidän ajatuksiaan yrittäjyydestä, josta on tullut Suomessa keskeinen, kaikki koulutustasot läpäisevä ihanne. Yrittäjäkasvatukseen näyttää rakentuvan sisäinen dilemma: yhtäältä yrittäjyyteen otetaan "kaikki mukaan”, toisaalta ihanteena on tietty keskiluokkainen ja maskutuksesta. Tuomaalan mukaan liininen toimintamalli, joka sulkee piiristään pois esimerkiksi kotikeskeisyyden ja epävarmuuden kaltaisia piirteitä. Myös Päivi Bergin kiinnostus on nykykoulussa, opiskelijoiden epätasaisesti jakautuneissa resursseissa harrastaa erilaisia liikuntalajeja. Bergin mukaan ruumis on koulussa resurssi etenkin niille oppilaille, joiden vanhemmilla on mahdollisuus kustantaa lapsilleen liikuntaharrastus.

Tarja Tolosen kirjoituksessa analysoidaan nuorten suhdetta koulutukseen ja työhön. Eri puolella Suomea tehdyissä haastatteluissa nuoret valottavat näkemyksiään menestymisestä, pärjäämisestä ja syrjäytymisestä. Aineiston perusteella näyttää siltä, että yksilöllisyyttä painottavan ajan individualismi ei ole kaikille itsestäänselvyys. Toisille yksilöllinen "minä” on helpompi saavuttaa kuin toisille. Nuorten elämänkulun individualistisia valintoja kuvaavat teoriat tuntuvat kuvaavan lähinnä keskiluokkaista kaupunkilaista elämäntapaa, eivät kokonaista sukupolvea, kirjoittaa Tolonen.

Naisille tyypillinen hoiva- ja siivoustyö valottuu kiinnostavasti kirjan kahdessa artikkelissa. Mari Käyhkö kuvaa artikkelissaan siivoojaksi opiskelevien nuorten työläistaustaisten naisten ajatuksia koulutuksesta ja työelämästä. Yksilöllisiä valintoja ja haasteellista työuraa painottava jatkuvan kouluttautumisen ihanne kyseenalaistuu nuorten naisten valinnoissa radikaalisti. Heidän tavoitteenaan on käytännönläheinen, ruumiillinen työ, äidiksi tuleminen ja perhekeskeinen elämä, joihin nähden liialli- 
nen koulupenkissä istuminen tai siisti sisätyö toimistossa näyttäytyvät kauhukuvina. Käyhkö korostaakin, että keskusteluista näyttää usein unohtuvan se, että kaikilla ei ole välttämättä halua tehdä "oikeita”, keskiluokkaisen kouluttautumisen valintoja. Siivoojiksi "ajautuneet" joutuvat jatkuvasti perustelemaan, puolustelemaan ja häpeämään valintojaan, sillä luokan jälkiä luetaan yleensä esimerkkinä yksilöllisistä epäonnistumisista, ei yhteiskunnallisesta epäarvoisuudesta.

Lena Näreen artikkeli avaa näkymiä siivous- ja hoitotyöhön
Italiassa. Jatkuvasti vanheneva väestö, julkisen sektorin kavennus ja muuttuneet työmarkkinat ovat johtaneet monissa muissakin Euroopan maissa siihen, että lapsista, vanhuksista ja taloudenpidosta vastaa yhä useammin siirtolainen. Siinä missä köyhien maiden miehet myyvät rikkaille maille lihastyövoimaansa, on köyhien naisten myyntiartikkeli usein hoiva. Hoivasiirtolaisuus ei ole uusi ilmiö, mutta sen muodot ja mittakaava ovat muuttuneet. Ensiarvoisen tärkeästä kodin hoiva- ja uusintamistyöstä on tullut niin halpaa, että myös keskiluokka voi sen avulla tavoitella eliitin elämää.

Kaiken kaikkiaan Yhteiskuntaluokka ja sukupuoli antaa paljon ajattelemisen aihetta kysymyksistä, jotka ovat ajankohtaisempia kuin arvaammekaan. Palkka-, koulutus- tai kulttuurierot eivät ole kadonneet, vaan niiden rooli ihmisten elämänkulukuja määrittelemässä on pikemminkin kärjistynyt. Palvelijayhteiskunta näyttää tekevän paluutaan.

\section{SANNA KIVIMÄKI}

